\title{
Specificity of conceptual development of information economy in Uzbekistan
}

\author{
T.Z. Teshabayev \\ Tashkent University of Information Technologies named \\ after Muhammad al-Khwarizmi \\ Tashkent, the Republic of Uzbekistan \\ tuit@tuitl.uz
}

\author{
Sh.I. Bobokhujaev \\ Department of "Economic Disciplines" \\ Gubkin Russian State University of Oil and Gas (National \\ Research University) in Tashkent \\ Tashkent, the Republic of Uzbekistan \\ bobshuh@mail.ru
}

\author{
Z.M. Otakuziyeva \\ Technology of postal communication \\ Tashkent University of Information Technologies named \\ after Muhammad al-Khwarizmi \\ Tashkent, the Republic of Uzbekistan \\ zukhra.otakuzieva@rambler.ru
}

\begin{abstract}
Information economy represents a new economy, which is aimed at expanding the development of human capabilities. The formation of information economy in Uzbekistan is inextricably linked with the development of information and communication technologies, characterized by several stages of development. The current stage of development of information and communication technologies in the republic is characterized by the period of formation and high dynamics in development. However, the growing importance of the information economy formation, as a dominant factor in the development of economy of the republic, has not yet been adequately reflected in economic research. It gives particular importance for the research on formation prerequisites and specific features of development of the information economy in Uzbekistan. The purpose of research is to study and analyze the development of information economy at present stage of world informatization, to identify the main problems of its development in Uzbekistan and to propose measures to eliminate them. In order to achieve the goal in their research, authors intend to analyze and characterize the prerequisites for the emergence, formation and development of information economy.
\end{abstract}

Keywords- information economy, information and communication technologies, information products, services sector, index, indicator

\section{INTRODUCTION}

The beginning of the XXI century can be considered as a starting point of the development of the world economy's new stage - the information economy (IE). The main factor of its development is the synthesis of science and innovation sectors, the education system, where the transformation process from the "material" society to "information" society is occurring on the basis of production, dissemination and consumption of information. Therefore, modern economic science is on the verge of forming a new paradigm that reflects today's reality of all-round use of information technologies, the influence of which led to a new organization of the economic system. The substantial analysis of IE was conducted in the works of such researchers as M. Porat, D. Bell, W. Daizard, M. Castells, M. Connors, U. Martin, A.Norman. The category IE was introduced into science in 1976 by American economist M. Porat, who analyzed its main problems a year later [1].

\section{A. The role and place of IE in enterprises' activities.}

Today, in modern economy the success of activities of any enterprise, firstly, is characterized by indicators of making operative and effective management decisions that are associated with rapid access to the necessary information in the system of information and communication technology (ICT). As a consequence, the development and introduction of new ICT is very important for enterprises of the republic, as it allows the companies of the information sector to acquire a special status of leaders that provide the economy with an information resource at the present stage. It is also important to note that there is a transformation of forms and methods of production, changing the parameters and properties of the products (services), as well as the creation of new products (services).All these changes and tendencies can be attributed to IE, which is characterized by a number of features. First, knowledge and information objectified in products and services constitute an increasing part of the value created. Secondly, activities related to the production and processing of information and knowledge are becoming increasingly important, which is reflected in growth proportion of workers engaged in these processes, up to the half or more of employable population of the country. Thirdly, there is an increasing transformation of economic activity from a combination of production processes into a set of functions: design, supply, transportation, sale of products. Fourthly, the rapid transformation of previously unique products into ordinary, rapid obsolescence of technologies, 
marketing ideas and professions is occurring, and it forces to generate accelerated information. Fifth, the increasing role of management in the administration of the development and dissemination of ICT as a way of reducing the strategic errors associated with their use. Sixth, the parameters of information and technological cycles are being changed. Seventh, the basic infrastructure for IE is a network for transferring the information, the development of IE is almost impossible without using the network.

\section{$B$. The development stages of ICT in Uzbekistan}

To date, the President, the Government of the Republic of Uzbekistan pays special attention to the development of ICT and its mass implementation in all spheres of society. This is facilitated by adopted Integrated Program for the Development of National Information and Communication System of the Republic of Uzbekistan, designed for 2013-2020. The development of ICT in Uzbekistan is characterized by several stages [2, p.245]:

1. The initial stage of ICT development in Uzbekistan was from 2000 to 2002. At this time, work on improving public administration through the phased introduction of ICT was done. For this period, the Institute of Communication of Uzbekistan was transformed into the Tashkent University of Information Technologies named after Muhammad-alKhwarizmi and training of qualified specialists in the field of ICT has started;

2. The second stage falls on the period from 2003 to 2007. In this period, the main legislative and regulatory documents were adopted for the extensive introduction of ICT. State programs have been adopted for the computerization and equipping of state institutions, a large-scale digitalization of fixed telecommunications network has been launched;

3. The period from 2008 to 2012 can be characterized as the period of launching ICT mechanisms introduction in the state. This period reflects the beginning of active implementation of internal information systems and software products in state bodies, rendering of information and reference electronic services.

4. The period from 2012 up to the present is the period of spread of ICT in all spheres of life. In this period, there is a further improvement in the structure of public administration.
TABLE I. THE DYNAMICS OF CHANGES IN THE UNO E-GOVERNMENT RATING OF THE REPUBLIC OF UZBEKISTAN [3]

\begin{tabular}{|l|c|c|c|c|c|}
\hline \multicolumn{1}{|c|}{ Index } & $\mathbf{2 0 0 8}$ & $\mathbf{2 0 1 2}$ & $\mathbf{2 0 1 6}$ & $\mathbf{2 0 1 8}$ & $\begin{array}{c}\text { Change } \\
\mathbf{2 0 1 8 / 2 0 0 8}\end{array}$ \\
\hline $\begin{array}{l}\text { E-Government } \\
\text { Rank }\end{array}$ & 109 & 91 & 80 & 81 & +28 \\
\hline $\begin{array}{l}\text { E-Government } \\
\text { Index }\end{array}$ & 0,40570 & 0,50991 & 0,54335 & 0,62070 & $+0,21500$ \\
\hline $\begin{array}{l}\text { E-Participation } \\
\text { Index }\end{array}$ & 0,09090 & 0,23680 & 0,67797 & 0,75840 & $+0,66750$ \\
\hline $\begin{array}{l}\text { Online Service } \\
\text { Index }\end{array}$ & 0,27424 & 0,49673 & 0,68841 & 0,79170 & $+0,51746$ \\
\hline $\begin{array}{l}\text { Human Capital } \\
\text { Index }\end{array}$ & 0,90882 & 0,82544 & 0,69535 & 0,73960 & $-0,16922$ \\
\hline $\begin{array}{l}\text { Telecommu- } \\
\text { nication } \\
\text { Infrastructure } \\
\text { Index }\end{array}$ & 0,03811 & 0,20748 & 0,24630 & 0,33070 & $+0,29259$ \\
\hline
\end{tabular}

Over the years of implementing the Comprehensive Development Program of National Information and Communication System, the industry's contribution to GDP has increased from $1.9 \%$ to $2.2 \%$. The majority of the republic's indices in the UNO rating on e-government have significantly improved (See Table 1).

\section{PROBLEM STATEMENT}

To date, the President, the Government of the Republic pay special attention to the development of ICT and its mass implementation in all spheres of society. This is facilitated by the adopted Integrated Program for the Development of National Information and Communication System of the Republic of Uzbekistan, designed for 2013-2020. Nevertheless, the steps taken are insufficient and do not bring the expected results. In his speech, at extended session of the Cabinet of Ministers dedicated to results of the country's social and economic development in 2016 and the most important priority areas of the economic program for 2017, President of the Republic of Uzbekistan Sh.Mirziyoyev noted that "There is not a proper initiative to introduce ICT, even those who are in acute need for technological processes improvement and the management system of large enterprises, organizations and business associations "[4].Moreover, at the beginning of this year, a meeting devoted to the consideration of effectiveness of taken measures to develop information and communication technologies in Uzbekistan and ensuring information security was held, where President of the Republic of Uzbekistan Sh.Mirziyoyev also noted that "in the field of information technologies there is still much to be done; the achieved results do not reach the activities of other countries"[5].

\section{RESEARCH QUESTIONS}

Currently, the main development trend for any country is effective construction of information economy. Now, not only clear representation of the origins of digital age formation is important, but also the ability of foreseeing future prospects is needed.

Information economy is a new economy that aims to expand human development opportunities, and also contributes to growth of well-being through the use of information, knowledge and innovative technologies. The area of IE includes 
an information society and space, ICT and various types of production, rendered services, productive and non-productive infrastructure [6, p.50]. In IE, the processes of generation, processing, accumulation and transmission of information through the ICT system are being investigated. These processes are carried out in integrated network among producers of information, equipment and information transmitters, as well as its consumers, the state and civil society. The production and consumption of information product is the main driving force of IE. Demand and supply of information product in the market is determined by specific factors and mechanism of the operation of market laws.

\section{A. The formation of IE in Uzbekistan}

The IE of each specific country is formed individually, and due to the fact that information society is formed all together, where everything is interconnected (economy, politics, science, technology progress, etc.), the information economy of each country assumes a global formation character. The two main components in IE are:

1) deep understanding of information role in the current development environment, since the notion of information economy is secondary;

2) the basis for current information economy formation of the country is the existence of a full-fledged information market.

The actual stage of development of IE can be characterized as a period of formation. This period of development is characterized by combination of maximum uncertainty of future states, on the one hand, and high dynamics of development, on the other. The second characteristic feature of formation stage is a combination of trends towards the renewal or destruction of old structures (institutions, relations, agents) and simultaneous formation of new ones.

The formation of IE in the republic is stipulated by the increased role of those types of economic activity that are associated with the production of intellectual products and services, and with corresponding structural changes in the national economy. The functioning of information economy reflects recognition of the fact that theoretical knowledge directly determines the parameters of its growth, creating the basis for innovation and formation of human capital.

In Uzbekistan, the basis of IE is a set of industries in the service sector, characterized by significant big contribution of value from human capital in comparison with material elements. There is an increasing dependence of functioning of some industries on information from generated and accumulated information in others. Moreover, it is the case of increasing share of data-intensive services such as: education, innovation, information and communication and intellectual services.

\section{$B$. The system of indicators of the IE formation}

An actual issue in the process of transition to information society was the creation of an efficient complex system of indicators of informatization and methods of its practical use. For estimation, the degree of information economy development, several indicators such as the index of digital opportunities, the index of countries' readiness for egovernment and etc. are used. Building an effective system of indicators for the information economy formation is a guarantee of successful monitoring of implementation the state development programs. However, even in developed countries, the concepts and statistical indicators of information technology sector are not yet fully formed.

Based on a comparative analysis of theories on IE and traditional characteristics of its quantitative and qualitative parameters, a list of criteria allowing the identification of actual stage of the information economy development can be offered:

- from the position of development of productive forces mass computerization, the typicality in use of information technology;

- the formation of Internet business models based on processing data from material objects connected to the Internet;

- in the context of transformation of subject structure of information economy - the co-optation of the institutional structures of civil society in the number of its subjects .

There are many methodological approaches to assessing the level of informatization of both the economic system and public authorities. Nevertheless, until now there is no method for allowing an analysis of information economy in all its aspects.

\section{PURPOSE OF THE STUDY}

According to the authors, the research hypothesis is that the IE will take the leading position due to the rapid development of the information sector in Uzbekistan. The purpose of research is to study and analyze the development of IE at present stage of world informatization, identify the main problems of its development in the Republic of Uzbekistan and to develop proposals for their overcoming. The authors' position is that the republic is at the stage of transition to IE and they are convinced that there is a need for large-scale comprehensive research.

In order to achieve the goal, the following tasks are set:

- to characterize the prerequisites for the emergence, formation and development of information economy;

- to study theoretical interpretations of information economy;

- to reveal the specifics of the institutional structure of information economy and the place of its basic institutions in it;

- to investigate the electronic government of Uzbekistan as a key element of the institutional structure of information economy.

The main factor in the development of IE is the synthesis of science and innovation sectors, the education system, where the process of transition from a "material" to an "information" society based on production, dissemination and consumption of information occurs. Therefore, modern economic science is on the verge of forming a new paradigm that reflects today's reality 
of the all-round use of information technologies, which influence led to new organization of the economic system.

\section{RESEARCH METHODS}

The use of a comparative analysis of IE models of several countries in a scientific study will determine the development of following new trends:

- the division of traditional and information economy, i.e., the definition of those areas in which the implementation of information technology is carried out most quickly and efficiently: information and communication, finance, health care, education;

- the formation of contradiction between the information economy and the branches of economy of industrial era, which is gradually being mitigated by the penetration of information technologies into industrial production;

- inclusion in globalized economy, which increases the degree of instability of national economy.

Conducting a comparative analysis of the country IE models enables one to single out its general features that are characteristic to all its national models:

- the formation of a fundamentally new fifth technological order, based on the use of information and knowledge;

- creation of a global digital information environment;

- restructuring of employment in the direction of its remoteness;

- the direct dependence of life quality on the level of information resources consumption;

- an escalation of the problem of ensuring information security.

Qualitative categorical analysis of IE implies its quantitative assessment. In the world practice, to assess the development level of information economy, large-scale methods are used to build the rating indicators, which include the network readiness index, the digital opportunities index, the countries readiness index for the electronic government and etc.

\section{FINDINGS}

In order to develop ICT and build an information society in the Republic of Uzbekistan, a number of laws such as "On Informatization", "On Electronic Digital Signature", "On Electronic Commerce", "On Electronic Document Management", "On Electronic Payments", etc. have been adopted. Moreover, more than 20 resolutions and decrees of the President of the Republic of Uzbekistan and more than 30 governmental decisions on the development and implementation of new information systems, technologies, interactive services, and the development of skills in the field of ICT came out. In addition to these laws and regulations, the structure of Uzbekistan e-government system includes the following components: a single portal for interactive public services (SPIPS) for direct contact with recipients of public services; portal of open data (data.gov.uz) - open data and statistics from state bodies; direct sites of state bodies; complexes of information systems "Tax", "Customs", "Education" and others, through which the state bodies "communicate" with each other. The virtual reception of the head of the state and the portal of housing and communal services takes place.

SPIPS, which functions within the Governmental portal of the Republic of Uzbekistan on the Internet, was launched on July 1, 2013. Through the Single Portal, interactive services are provided to population and business entities in various directions and spheres of activity. More than 600 government agencies and their structural subdivisions are connected to the Single Portal. Today, SPIPS has introduced more than 308 types of services that enable citizens and business entities to solve their questions quickly and easily.Answers to these questions are provided by more than 2,433 state and economic management bodies.

Along with this, since 2006, centralized record and registration of state resources and information systems of state bodies aimed at forming a single information space on the territory of the Republic of Uzbekistan and organization of information interaction of state bodies of the Republic of Uzbekistan have been conducted in the country.

In order to provide a single point of access for citizens to the relevant interactive public services provided by public authorities, providing citizens and organizations with a single interface to access information from public authorities and to obtain public services with the access to the website of authority that are responsible for providing specific interactive state services, the Register of Basic Interactive Public Services is carried on.

\section{Analysis of the service sector of the republic}

The analysis shows that over the last 7 years the total volume of the republic's service sector has increased almost 4.5 times and amounted to $47.3 \%$ of GDP; communication and information services goes up more than 3.8 times (see Fig. 1). The production volume of services for 2017 amounted to 116795.7 billion UZS and increased by $8.9 \%$ [7]. In 2017 , the volume of communication and information services amounted to 7942.1 billion UZS, which is $6.7 \%$ of the total volume of services. The basis for increase in the volume of production of services is the influence of a number of factors, such as the appearance of new types of services on the market, opening of new shopping centers, catering organizations, hotels, expansion of educational services and entertainment industry. 


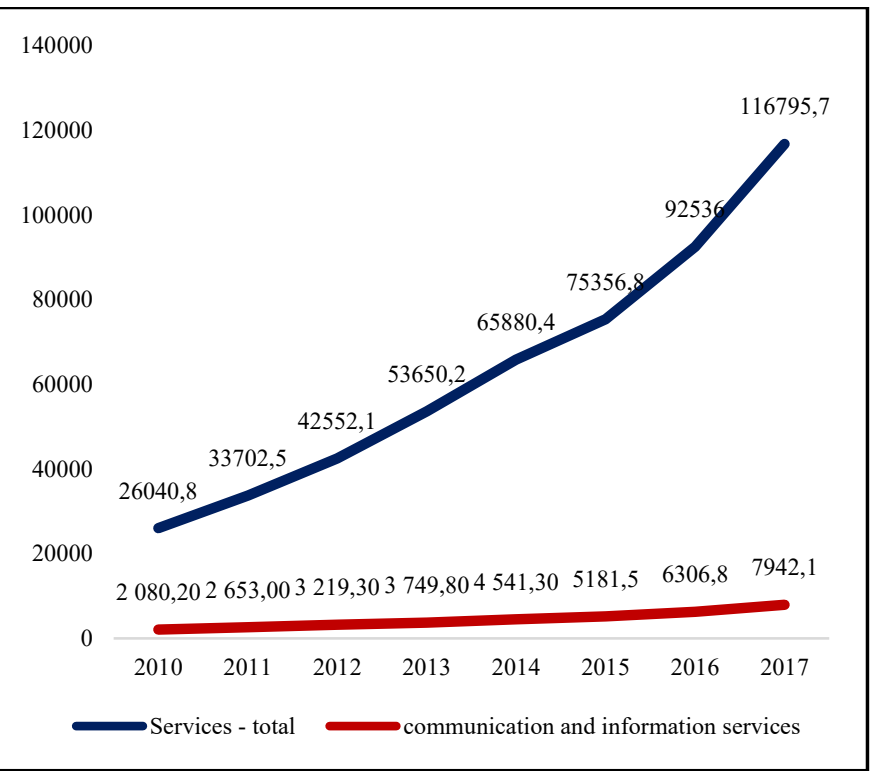

Fig. 1. The dynamics of changes in the volume of services provided for 20102017, in billion UZS [8]

At the same time, in 2010 - 2017, the share of communication and information services decreased from 8.0 to $6.8 \%$. In 2017, in the volume of communication and informatization the largest share $(87.3 \%)$ accounts for telecommunications services (wireline and mobile services, Internet, satellite communication services, etc.) (see Fig.3).

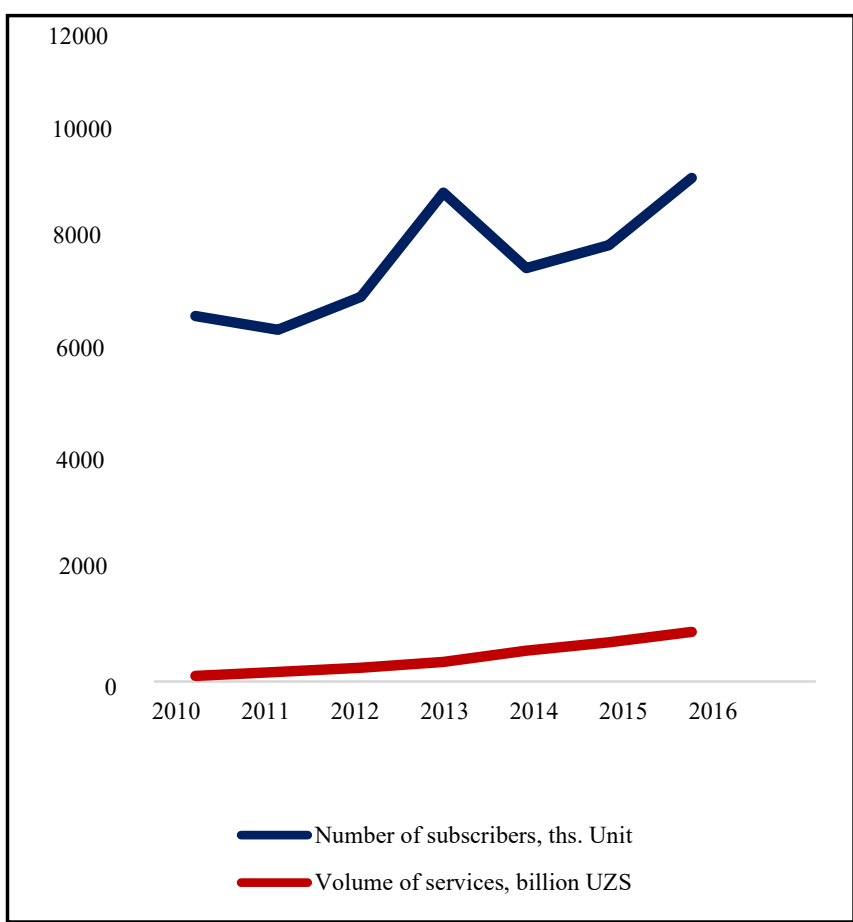

Fig. 2. The dynamics of growth in the number of subscribers and the volume of Internet services for 2010-2017 [9]

In the sphere of telecommunication services, the growth of wireless telephony services, an increase in the number of cellular subscribers and the points of collective access to the Internet are observed (see Fig. 2).
Analysis of activities of economic entities in the field of communications and informatics

According to the results of 2016, the provision of population with mobile communication per 100 people comprised 65.3 units. According to the data of the Ministry for Development of Information Technologies and Communication of the Republic of Uzbekistan, the capacity of international data transmission channels was $54980 \mathrm{Mbit} / \mathrm{s}$ and increased almost 21 times compared to 2010 (2510 Mbit / s).

Within the framework of the Comprehensive Development Program of National Information and Communication System of the Republic of Uzbekistan in 2016, over 2,300 kilometers of fiber-optic broadband access networks using modern technologies were built and reserved [10]. Investments in fixed capital in the sphere of information and communications in 2016 amounted to 1150.4 billion sums, which is $2.3 \%$ of the total, and 1085.5 billion UZS out of it $(2.2 \%)$ account for communications [11].

The total share of used foreign investments and credits in 2016 was $7.2 \%$. The number of economic entities operating in the field of communications and informatics is 6900 enterprises (2.4\% of the total number of enterprises), of which 6,400 (2.4\%) were operating enterprises [10]. In 2016, the number of state information resources (SIR) reached 318 units, and the number of state information systems (SIS) exceeded 485 units, which shows an increase of 1.6 and 5.0 times respectively in recent years $[13 ; 14 ; 15, \mathrm{p} .210]$.

The contribution of enterprises providing communication and information services for budget of the republic amounted to 1.5 trillion UZS $(3.6 \%)$ in 2016 . In recent years, there has been a change in the dynamics of revenues received by communication and information enterprises - the share of contribution of mobile communication enterprises is decreasing and Internet providers are increasing (see Fig. 3). 


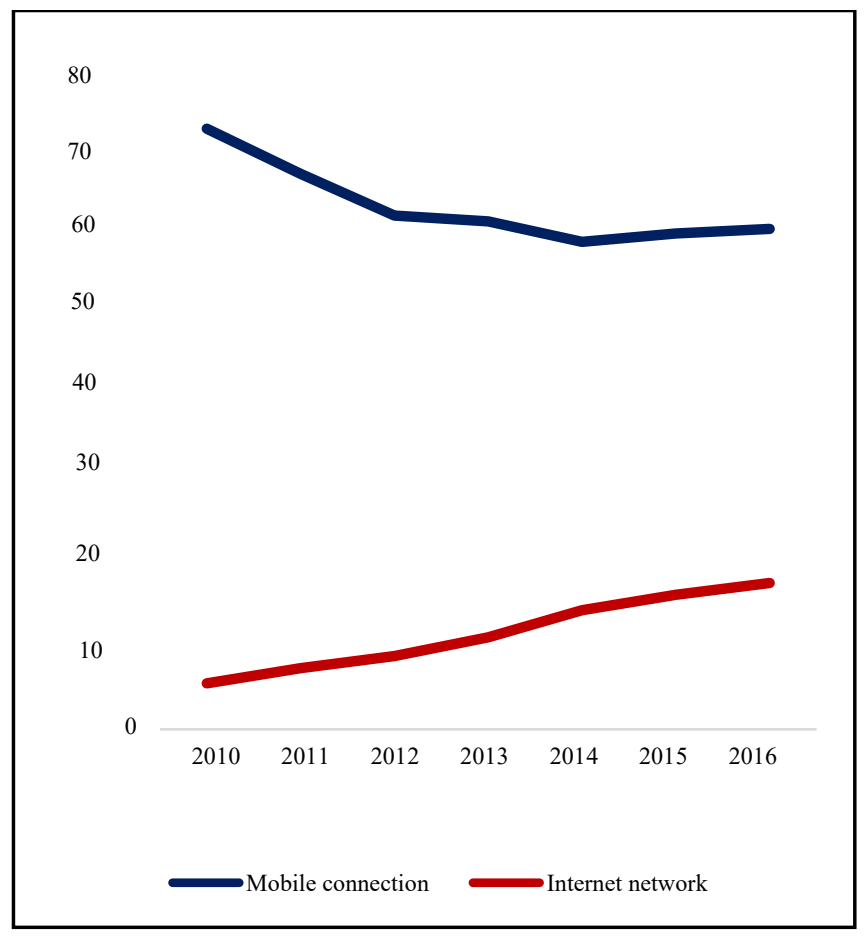

Fig. 3. Dynamics of the change in the revenue of telecommunications enterprises from rendering services, in $\%$ [12]

In Uzbekistan, the formation of IE is inextricably linked with the development of ICT and it is characterized by such indicators as the science-intensive economy, the share of services in GDP, etc. Unfortunately, research related to the formation and development of IE in Uzbekistan has not been conducted so far. These scientific researches allowed studying and analyzing the problems of modern ICT introduction at the enterprises of the republic, as well as the role and development of IE at the present stage, to reveal the condition of formation and development of IE in Uzbekistan and to offer recommendations for development [16, p.52]. At the same time, some scientists, as a result of studying the creation of the information economy, came to the conclusion that the existence of the information economy is controversial. However, despite this, there are certain prospects for its development of the information economy [17, p.9].

\section{CONCLUSION}

The conducted analysis showed some features of emerging model of IE, which are due to the prevailing conditions of its formation and they are reflected by following parameters:

- the peculiarity of the ICT system formation is its state character, since its formation was initiated at the state level and it is implemented by the Comprehensive Development Program of National Information and Communication System of the Republic of Uzbekistan (2013-2020);

- the main objectives of the development of ICT and IE are determined by government bodies and are consistently implemented at all levels of government, so its scalability reflects the national-regional character;
- the model of IE is characterized by a social orientation, since its main goal is to benefit citizens and organizations from the use of ICT and create conditions for operative and effective interaction of the state with citizens and business;

- the formation and use of results of the IE development requires certain technological knowledge, which necessitated the formation of the national system for increasing computer literacy and continuous improvement of users skills, primarily government employees;

- the multinational state objectively determines the formation of a multicultural digital environment for interaction of IE subjects.

The results of proposed scientific research can be used by government agencies in effective formation and evaluation of the level of IE development in the country to reveal the features of electronic commerce and e-employment in the status of basic IE institutions; to identify the problems of introduction of modern ICT and the development of IE at enterprises of the republic; to reveal the condition of e-government activity, exchange electronic trading systems of Uzbekistan, Internet shops, the main branches of the service industry and etc.

\section{Acknowledgment}

In general, it can be noted that the development strategy of National Information and Communication System of the Republic of Uzbekistan shows a trend of rapid growth. The active introduction of ICT leads to transformation of the role of information, structural imbalances in the labor market, the growing interdependence of functioning of certain industries from others, an increase in the role of science-intensive economy and the share of services in GDP. However, the lack of assessment of the interdependence level between the functioning of certain industries and generated and accumulated information in others will not allow the development of effective measures for a sufficient development level of enterprises in the sphere of communication and information services. The guarantee of successful implementation of state programs for the development of ICT is the construction of an effective system of indicators of the information economy on the basis of large-scale scientific research.

\section{References}

[1] V. Porat, The Information Economy Definition and Measurement. Washington DC: US Dept of Commerce, 1977, p.71.

[2] Sh.I. Bobokhujaev, Z.M. Otakuziyeva, "Information economy: world tendencies and specifics of development in Uzbekistan", Innovative economy and social infrastructure: a collection of scientific articles. Part two. Tashkent: Publishing house LESSON PRESS, pp. 241-249, 2015.

[3] United Nations. (2018). UN E-Government Knowledge Database Department of Economic and Social Affairs. Retrieved from https://publicadministration.un.org/egovkb/en-us/Data-Center.

[4] Official web site of the President of Republic of Uzbekistan. Report of the President of Republic of Uzbekistan Sh.M. Mirziyoyev "Critical analysis, strict discipline and personal responsibility should become an everyday norm in the activities of each leader". Retrieved from http://prezident.uz/ru/lists/view/187. 
[5] Official website of the President of Republic of Uzbekistan. The president conducted a panel for the development of ICT sphere. Retrieved from http://prezident.uz/ru/lists/view/1414.

[6] O.V. Pachkova, Actual questions of correlation of the main concepts of in formation economy. Herald of Siberian University of consumer cooperation. Novosibirsk 3(6). Pp.48-52, 2013. Retrieved from http://elibrary.ru/download/19685494.pdf.

[7] The web site of State committee of the Republic of Uzbekistan on statistics. The development of service industry. The statistics of services. January-December 2017 (preliminary data). Retrieved from https://stat.uz/uploads/docs/\%D0\%A3\%D1\%81\%D0\%BB\%D1\%83\%D $0 \% \mathrm{~B} 3 \% \mathrm{D} 0 \% \mathrm{~B} 8 \% 20 \% \mathrm{D} 0 \% \mathrm{~B} 7 \% \mathrm{D} 0 \% \mathrm{~B} 0 \% 20 \% \mathrm{D} 1 \% 8 \mathrm{~F} \% \mathrm{D} 0 \% \mathrm{BD} \% \mathrm{D} 0$ $\% \mathrm{~B} 2 \% \mathrm{D} 0 \% \mathrm{~B} 0 \% \mathrm{D} 1 \% 80$

$\% \mathrm{D} 0 \% \mathrm{~B} 4 \% \mathrm{D} 0 \% \mathrm{~B} 5 \% \mathrm{D} 0 \% \mathrm{BA} \% \mathrm{D} 0 \% \mathrm{~B} 0 \% \mathrm{D} 0 \% \mathrm{~B} 1 \% \mathrm{D} 1 \% 80 \% \mathrm{D} 1 \% 8 \mathrm{C}$ $\% 202017 \% 20 \% \mathrm{D} 0 \% \mathrm{~B} 3 \% \mathrm{D} 0 \% \mathrm{BE} \% \mathrm{D} 0 \% \mathrm{~B} 4 \% \mathrm{D} 0 \% \mathrm{~B} 0 \% 20(\% \mathrm{D} 1 \% 80 \%$ D1\%83\%D1\%81).pdf.

[8] The web site of State committee of the Republic of Uzbekistan on statistics. Services of the main types of economic activity in (2010 - 2016). Retrieved from https://stat.uz/ru/ofitsialnaya-statistika/sferauslug/uslugi/2453-uslugi-po-osnovnym-vidam-ekonomicheskojdeyatelnosti-v-2010-2016-godu.

[9] The web site of State committee of the Republic of Uzbekistan on statistics. The development of service industry. Retrieved from https://stat.uz/ru/press-tsentr/novosti-komiteta/433-analiticheskiematerialy-ru/2046-razvitie-sfery-uslug.

[10] The web site of the Ministry of Economy of the Republic of Uzbekistan. On the results of social and economic development of the Republic of Uzbekistan for 2016.Retrieved from https://mineconomy.uz/ru/node/1478.
[11] The web site of State committee of the Republic of Uzbekistan on statistics. Statistical Review of Uzbekistan for 2016, p.33. Retrieved from https://stat.uz/uploads/doklad/2016/doklad-2016-yanvar-dekabr-ru.pdf.

[12] The web site of State committee of the Republic of Uzbekistan on statistics. Structure of the revenue of communication entities from rendering communication services (in \%). Retrieved from https://stat.uz/ru/ofitsialnaya-statistika/sfera-uslug/svyaz/2427-strukturavyruchki-predpriyatij-svyazi-ot-okazaniya-uslug-svyazi.

[13] The web site of State committee of the Republic of Uzbekistan on statistics. Statistical Review of Uzbekistan for 2016, p. 7. Retrieved from https://stat.uz/uploads/doklad/2016/doklad-2016-yanvar-dekabr-ru.pdf.

[14] The web site of State committee of the Republic of Uzbekistan on statistics. The development of communication and information services in January-December 2016. Information service of State committee. http://www.stat.uz/ru/press-sluzhba/novosti-gks/1529-razvitie-uslugsvyazi-i-informatizatsii-za-yanvar-dekabr-2016-goda.

[15] The website of the Ministry for development of Information technologie and communications of the Republic of Uzbekistan. Indicators of industry development http://mitc.uz/ru/activities/indicators industry development/.

[16] Sh. I. Bobokhujaev, Z.M. Otakuziyeva, "Features of formation of information economy", Herald of TUIT. №3 (35), pp. 206-212, 1015

[17] A.G. Zaytsev, L.V. Plakhova, S.A. Legostaeva, N.V. Zakharkina, Y.A Zviagintceva, "Establishment of Information Economy Under the Influence of Scientific and Technical Progress: New Challenges and Possibilities", Pyatigorsk; Russian Federation, pp.3-10, 1 February 2018 [5th National scientific and practical conference on Perspectives on the use of New Information and Communication Technology (ICT) in the Modern Economy, p.9, 2018] 